\title{
Building a Conducive Learning Environment in Dysfunctional Schools: A Curriculum Development Tool
}

\author{
Mutendwahothe Walter Lumadi \\ Department of Curriculum and Instruction, College of Education, \\ University of South Africa, South Africa \\ Lumadmw@unisa.ac.za
}

\section{Doi:10.5901/mjss.2014.v5n6p319}

\begin{abstract}
The dearth of expertise in mathematics and science in South African schools in general and in the Limpopo province in particular is a daunting task. The annual National Senior Certificate examinations results are a testimony to this pathetic and unenviable situation. This situation warrants the immediate intervention of the Ministry of Basic Education and academics from institutions of higher learning, who can assist by providing resources to create a conducive learning environment in dysfunctional schools. A qualitative phenomenological design was employed in this study to explore the curriculum experiences of the interviewees. The research approach provided participants with an opportunity to describe and interpret the experiences of the phenomena as they were lived-out in a natural setting. The University of South Africa, College of Education rescued the situation by appointing expert teachers from the Dinaledi schools to offer extra classes on Saturdays and school vacations to the affected schools.
\end{abstract}

Keywords: Curriculum development, recruitment, retention, distributive leadership, Vhembe district, Limpopo Province, Dinaledi (star) schools, circuits

\section{Introduction}

Although this study shed light on dysfunctional schools in the Vhembe district in South Africa, where these schools obtained a $0 \%$ pass rate in mathematics and science, teachers all over the world have the opportunity provided through technology to change what is happening in schools and to educate children so that they can compete in the now increasingly globalised world market. The quality of education in South Africa is compromised by a number of factors, including: the educational background of teachers, their teaching experience, the teacher-learner ratio, class attendance, the pedagogic content knowledge of teachers and the limited career development opportunities for teachers (Duignan, 2006; Leithwood \& Jantzi, 2000).

\section{Literature Review and Theoretical Framework}

The distributive leadership theory underpins this study. The study further argues that the distributed perspective offers a new and important theoretical lens through which leadership practice in school can be reconfigured and reconceptualised. This is a recent theory, which is receiving much attention and growing empirical support (Gronn, 2000; Spillaine, Halverson, \& Diamond, 2001). In their recent review of successful school improvement efforts, Glickman, Gordon and Ross-Gordon (2001:49) cite varied sources of leadership, including distributed leadership at the top of the list of what makes successful schools. Similarly, Silns and Mulford (2002) found that where leadership sources are distributed throughout the school community, student outcomes are more likely to improve. Emanating from the above studies and the viewpoints expressed in relation to distributive leadership theory, this paper focuses on the role and responsibilities of the principal as the instructional leader, but it also recognises that the principal can delegate some of these roles and responsibilities to teachers at school. This is particularly so if teachers are empowered in areas of importance to them. The distributive leadership construct can be applied to the South African context, because it is embedded on the principles and values of democracy, shared leadership and inclusivity.

It is through definition and action, as well as the right knowledge and tools, that principals and teachers can take control of themselves and their environment - defining, thinking and controlling their choices into the future. It follows that people can only know what is going on if they understand what the participants themselves believe about their world. For this reason research should focus on collecting, analysing and interpreting the various perspectives of principals in a 
school setup (Gurr, 2001).

\section{Method}

Students, teachers and principals from the Vhembe district were interviewed (see figure 1 and table 1 for details of participants).

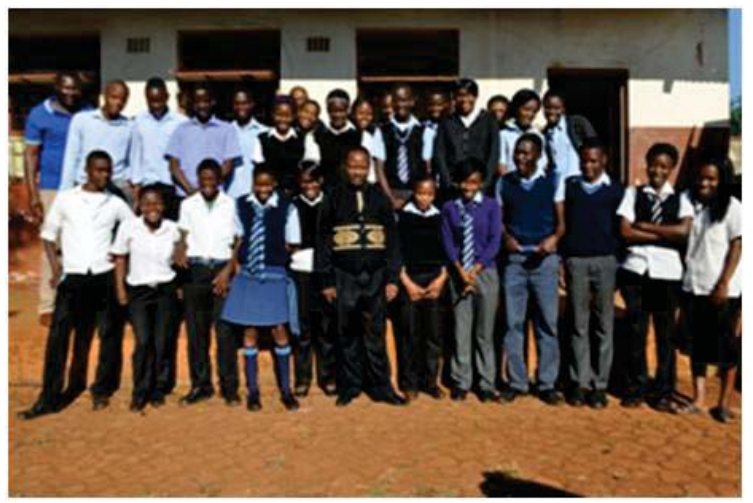

Figure 1: Grade 12 students from a disadvantaged school

In the above picture are grade 12 students, a mathematics teacher (back row) and the project leader (MW Lumadi, front row, centre). The above picture was taken from one of the disadvantaged schools on Saturday's intervention programme. Students were dedicated to their studies hence they did not have a problem of attending classes on weekends and school vacations. Based on the findings from the study, it was imperative that the University of South Africa, Department of Curriculum and Instructional Studies came up with a turn-around strategy of securing the services of experienced teachers from the Dinaledi (star) schools to teach mathematics and science in the dysfunctional schools.

Table 1: Details of participants

$\begin{array}{lcc}\quad \text { Frequency } & \text { F } & \% \\ \text { Gender } & 12 & 50 \\ \text { Male } & 12 & 50 \\ \text { Female } & & \\ \text { School subjects } & 12 & 50 \\ \text { Mathematics } & 12 & 50 \\ \text { Physical Science } & & \\ \text { Position } & 8 & 33.3 \\ \text { Teacher } & 8 & 33.3 \\ \text { Learner } & 4 & 16.6 \\ \text { Principal } & 4 & 16.6 \\ \text { SGB member } & & \\ \text { Teaching experience } & 2 & 8.3 \\ \text { 0-4 } & 12 & 50 \\ \text { 5-7 } & 8 & 33.3 \\ \text { 8-10 } & 2 & 8.3 \\ \text { +10 } & & \\ \text { Circuits at Vhembe district } & 6 & 25 \\ \text { Tshinane } & 6 & 25 \\ \text { Sagole } & 6 & 25 \\ \text { Sibasa } & 6 & 25 \\ \text { Dzindi } & & \end{array}$




\title{
4. Findings and Discussion
}

\subsection{Theme 1: Scarcity of resources and facilities}

The state of infrastructural decay in many secondary schools in Vhembe district is a testimony of the poor application of the school funding system. A similar study conducted in Nigeria by Ahmed (2003) revealed that in most of that nation's secondary schools, teaching and learning takes place in the most unconducive environment, lacking the basic materials, which hindered the fulfilment of educational objectives. Although most teachers in the Vhembe district are better credentialed, more experienced and more talented than teachers in other districts, resources are crucial for them to exhibit expertise in the subjects they are teaching. Without resources, the learning content is likely to be presented in a haphazard manner and learners do not benefit as teaching becomes less effective. Teaching and learning in the Vhembe district is plagued by the enormous shortage of resources. A furious principal from school $\mathrm{X}$ remarked:

\begin{abstract}
"I am not shy to say that I got 0\% pass rate in a Grade 12 Physical Science in 2012. How on earth can I have effective teaching without the required facilities? The school does not have a laboratory for Science. How do I practice Chemistry experiments without a laboratory? I have been complaining for ages but it does not pay dividends. As long as nothing is done about it, history will repeat itself".
\end{abstract}

Although the ruling party in South Africa promised the public that they will provide school transport it is unfortunate that in some of the schools in the district, learners cannot access education because of the distance they have to travel to get tuition. A principal remarked:

\begin{abstract}
"The walking distance to this school is a mammoth task. Some students walk for $35 \mathrm{kms}$ in the morning. They have to cross a river by means of swimming and in the process books get wet or lost. Last month, a corpse for a Grade 12 student was discovered after being washed away by a river. Despite that profound loss, the department is yet to act. Many students are always absent when the river is full because there is no scholar transport from their homes to schools."
\end{abstract}

Learning in the affected schools can be taken to a higher level if there were suitable apparatus for the learners to use during the lesson. Teaching resources are important, but the effective use of resources is crucial. If teachers really want to get through to their students, they need to let them have fun every now and then. Commencing a school day with a lesson requiring note taking is adequate, but subjects like mathematics and physical science need some kind of handson activity to really make the material relevant. The best way to get students to be serious about learning is to make it as attractive and interesting as possible. The researcher had the opportunity to visit a couple of dysfunctional schools in the Vhembe district, in both urban and rural areas, and the lack of resources was appalling (see figure 2).

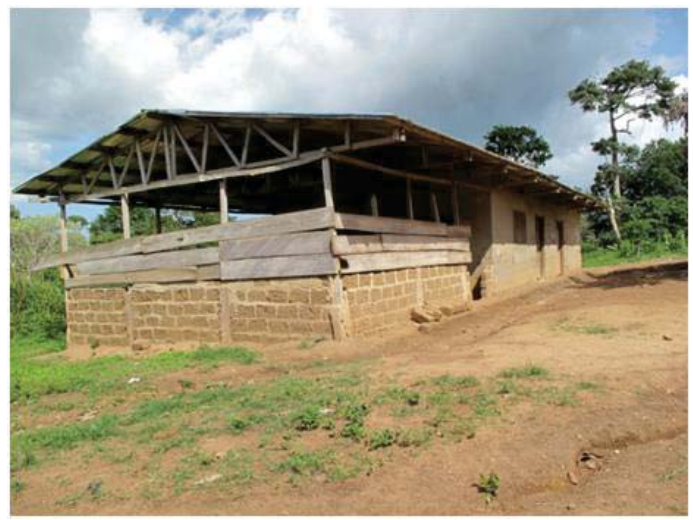

Figure 2: Condition of a disadvantaged school building

Principal X mentioned the following issues;

"It is shocking to tell you that in 2012, Grade 12 books were only delivered in April instead of October 2011 as promised. 
We do not even have a library for books. Computers were delivered in some schools except in our school. Although we were promised electricity two years ago, we are still waiting. The Department of Education does not care. All that is expected from us is to make sure that Grade 12 learners pass with flying colours despite all odds".

The fact that desktops and laptops were distributed to certain districts infuriates the senior management team (SMT). This resource disparity is regrettable, but it can be addressed head-on if the SMTs become more purposeful in decision-making and develop enforceable policies that make fairness and equal distribution a higher priority. The use of computers in teaching is vital. Teachers can get additional information from the internet that can be used to go into more depth about a lesson that is being taught. In the past, school teachers had a hard time when it comes to getting children to pay attention in class, but these problems have become less prevalent with the advancement of technology. The greatest challenges lie in the poorer, rural provinces like the Eastern Cape, Mpumalanga and Limpopo.

The following incident was cited by a principal:

\begin{abstract}
"In this school as you can see there are no toilets. During break students just go the bush to relieve themselves. There is a side which is meant for female students while another one is meant for male students. As for staff members we use a toilet for a neighbour closer to the school."
\end{abstract}

Another principal had the following to say:

"[It is] 18 years into democracy, the schools lack the basics such as water supply and sanitation and are often targets of crime and vandalism. Some of the schools are kraals for goats and cattle. There are those school buildings without roofs, some have leaking roofs. It is also difficult to teach in overcrowded classes where the abnormal ratio is 1:120. On the other hand, there are well-resourced former Model "C" schools, with computer and science laboratories, sports fields, swimming pools and libraries and top teaching staff".

As long as the allocation of resources remains as skewed as it is, where the majority of rural schools in the district are made of grass and thatched grass, with no piped water, no electricity and no modern technical equipment and as long as there is not affordable transport for both learners and teachers, effective teaching will not take place. Teachers worldwide are helped greatly by the resources that provide support for the contents they are delivering in the classroom. Resources help students understand the overall contents of the lesson. Moreover, they provide teachers with material which can be used to provide feedback to test whether the students have improved their understanding of the given subject. Without resources, the whole teaching process can be very boring and there would be no information that backs up the lesson that the teacher would be working on. The very basic purpose of a teacher is to convey information through the use of different media, whether that is a book or through teaching, to the student through a relatable content. This relatable content can come from many sources, but mainly from the teacher support that is provided through the school and the curriculum. Resources can also help the reliability of a teacher to their student. Sometimes the students feel that they do not quite understand what the teacher is trying to say about a topic. The reason for using resources, in this instance, is to provide a strong language base from which the teachers can draw, allowing for an easier verbal understanding in the classroom situation.

\title{
4.2 Theme 2: Recruitment and poor retention strategies
}

Recruiting a new teacher is a mammoth task for any organisation, and the complex work of schools makes suitable teacher identification and selection even more challenging. The increasing demand for high-quality teachers in schools means that the SMT and school governing bodies (SGBs) have to select teachers who are prepared to use contemporary curriculum approaches to improve teaching, learning and organisational performance. Recruitment practices are influenced by the supply and demand of the labour market, economic conditions, competitor practices and technology. In the teaching-learning situation, it can also be viewed as a dynamic process that differs from school to school, because each school has its own needs. A concerned principal mentioned the following:

"Some shortlisted candidates are interviewed and appointed at district level whilst some are just placed to schools without involving the SMT. They get referrals to school which is a bit shocking to some principals. The need to recruit should start at the school level and be forwarded to the district level. Last year we had a need of a Grade 11 and 12 mathematics teacher. The district sent someone who did not meet the requirements. It was a directive from above and we had to stick to that teacher but it was a disaster to our Grade 12 students. She got 2, 1\% pass rate which was a disaster to my school". 
Not only are schools failing to attract new teachers to the profession; they are also failing to retain them. Twentyfive (25\%) of the teachers who enter the profession leave within the first two years of teaching, and $50 \%$ is gone by the fourth year. In high-poverty schools with poor working conditions, the rate of overall teacher attrition is disastrously high. Between 2011 and 2013, one out of four teachers in the nation's high-poverty schools in the Vhembe district either left to teach in another school or dropped out of teaching altogether due to poor accommodation (See figure 3). Shortages of highly effective teachers have a disproportionate effect on low-income and minority students; they are about twice as likely to be assigned to inexperienced teachers who, on average, make far smaller annual learning gains than more experienced teachers.

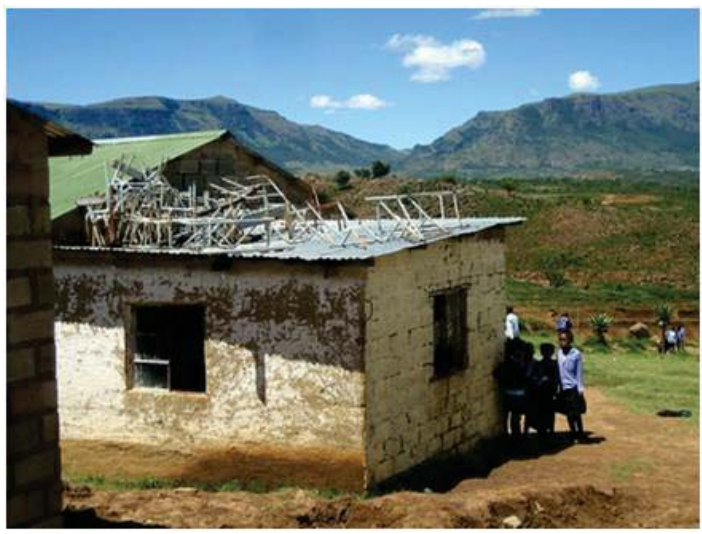

Figure 3: Teachers' housing complex

This old house is in attached to the school building. It is not looked after. It does not have ablution blocks nor electricity. When it is hot it becomes a problem to teachers and as a result they hardly spend more than a year. Every year, there is an exodus of teachers while new teachers come.

When making hiring decisions, principals and SGBs must consider the future of their schools. According to Lambert (2002), perceptions of teaching and learning have changed over the past ten years and expectations of schools, and the principals who lead them, have changed as well. Contemporary school principals' leadership responsibilities not only include the traditional task of efficiently managing students, staff and the school grounds, but also deep engagement in instructional and community issues (Whitaker, 2002). Contemporary school principals are being asked to build professional communities of reflective practitioners who critically consider how schools can improve learning and achievement of all students (Lambert et al., 2002).

The principal should establish an effective hiring committee that understands the specific curriculum needs of the school. Suitable candidates should be recruited, based on the criteria that best meet school and district goals. They must also identify the strongest candidates and conduct an onsite performance assessment of finalists (Farkas, Johnson \& Foleno, 2001). The urgency to recruit more cost effectively and to more accurately measure the output of employees after appointment can, in part, be attributed to the economic downturn. Nowadays teaching is one of the most complicated professions. It warrants in-depth knowledge of the learning content, curriculum and standards; and knowledge of discipline and classroom management techniques. With all these qualities required, it is no wonder that it is difficult for schools to find excellent teachers.

Teachers are the backbone of high quality public education and strengthening the teacher workforce can lay the foundation for fruitful investments in other areas of public education. Other studies demonstrate that the single most important factor determining how much students learn is the quality of their teachers. Teacher salaries and benefits are by far the largest education expenditure. The happier teachers are with their remuneration, the easier it becomes for students to learn. Wages are also the most critical resource for student learning.

Most districts in the province avoid the good practice during the selection process. Disregarding relevant data during the hiring process might have serious repercussions for the school and learners' results in particular. School district data and research is infrequently accessed when the selection committee makes critical decisions about personnel and instruction (Schlueter \& Walker, 2008). 
After the 2010 World Cup, South African teachers embarked on a national strike which continued for a few months. The grievance was related to annual salary increases. The department issued a warning to teachers, stating that teachers who do not return to their class will face disciplinary measures. It transpired that the Department of Education classified the days teachers were engaged in industrial action, as "leave without pay" days. This became evident when a certain amount was debited from their salaries for three months. The teachers unions intervened, but it was in vain. The principal of school $X$ reported the following;

"High failure rate in my school is related to several factors. A Grade 12 teacher, who taught Accounting, lost her car because the instalments' debit orders were not honoured for three months. That teacher resigned from the school without serving notice. For 3 weeks it was an inconvenience to our students. Although we got a substitute, it was not of the same calibre".

A very good teacher, as opposed to a very bad one, can make as much as one full year's difference in the achievement growth of students. Studies also show that high-quality leadership directly affects school performance as well as improves the working environment for teachers. Unfortunately, the provincial education leaders and public policymakers often fail to treat teachers and principals as the most valuable resources and the current policies are not effectively addressing their needs. Good teachers prefer a learner-centred approach as opposed to teacher-centred approach. They always surf the internet trying to solicit data that will improve the quality of their lessons and they are always punctual and lead by example. They present lessons in a clear and structured way. These teachers have lesson plans that give students a clear idea of what they will be learning. Marking of mathematics and physical science in 3 Grade 12 classes, of school $X$ taught by the same teacher was regarded as a nightmare because of overcrowding. Their classrooms are organised in such a way as to minimise distractions. A principal reports the following:

\begin{abstract}
"Being in a rural area is a disadvantage to our students. For the past three years, we have appointed $90 \%$ of new staff members. Every year there are resignations. Issues that are fuelling resignations are poor accommodation for teachers, no electricity, technology, poor network coverage of cell phones, no shops for food, poor transport to cities and no health facilities. A case of a hypertension teacher who collapsed in class was cited. This teacher died before reaching the closest clinic which is $225 \mathrm{~km}$ away from school. Retention needs attention because students are taught by new teachers annually and some of them resign before the end of the year. This has negative repercussions on students".
\end{abstract}

Schools with poor Grade 12 results should recruit teachers who will get students to look at issues in a variety of ways. These are teachers who use facts as a starting point, not an end point. They pose "why" and "how" questions in their continuous assessment. When a question is posed in the classroom, they refrain from choosing only students who raise their hands, but instead, they involve everyone. They encourage students to have dreams and to work toward realising these dreams. They expect that all students can and will achieve in their classroom and they do not give up on underachievers. In their feedback they indicate the weakness and response of students.

\title{
5. Recommendations
}

The recommendations made in these paragraphs are applicable to diverse aspects of teaching and should be listed separately.

$\checkmark$ Principals, as curricular leaders, must provide direction and support to teachers. They must provide direction in helping teachers identify, select, and develop programmes and materials that meet student needs within the context of the school's vision and mission.

$\checkmark$ Teaching and learning resources should be made available.

$\checkmark$ Facilities required in the school premises must also be availed.

$\checkmark$ Teachers' jobs should be guaranteed.

$\checkmark$ The change required of teachers and school leaders to use data for decision-making should not be underestimated. There are always those individuals who will resist change. Principals should take this into account when recruiting new teachers. They should not be tempted to wait until all teachers are on board before beginning to use data for decision-making.

$\checkmark$ Recruitment strategies for new staff members must be in place prior to appointment. Descent accommodation for teachers must also be provided. 


\section{Conclusion}

It is imperative to note that most South African schools in the Vhembe district do not have adequate resources such as sufficient books that are delivered on time; classrooms that are in immaculate condition, classroom furniture that is still intact and electricity. Parents and guardians find this situation pathetic as some of the identified schools do not have qualified teachers. It is in this vein that the University of South Africa, College of Education secured the services of experienced teachers from the Dinaledi (star) schools to teach mathematics and science in the dysfunctional schools. The university wishes to see the next generation of this democratic country live a better life. It is incumbent upon the Ministry of Basic Education to provide services to its citizens, and one of those services is to provide quality education to its people. As long as it does not change, the ruling party is purposely setting the children to be left behind in the African Continent and the global market at large. For this generation to be equipped with the skills to be able to compete with their neighbours and the global community will be a daunting task without proper support. Mathematics and physical science teachers should be equipped with the resources they need to teach these subjects effectively. Laboratories to conduct experiments in the classrooms are crucial to help students learn science and mathematics. Moreover, incentives to attract and retain experts to become teachers and stay in the teaching profession will go a long way in helping teachers to alleviate this huge problem.

\section{References}

Ahmed, T. M. (2003). Education and national development in Nigeria. Journal of Studies in Education. 10:35-46.

Duignan, P. (2006). Educational Leadership: Key Challenges and Ethical Tensions, Cambridge University Press, Melbourne.

Farkas, S., Johnson, J.,and Foleno, T. (with Duffett, A., and Foley, P.).(2001).A sense of calling: Who teaches and why. New York: Public Agenda. Retrieved February 19, 2010, from http://www.publicagenda.org/files/pdf/sense_of_calling.pdf.

Glickman, C. Gordon, S. and Ross-Gordon, J, (2001), Supervision and Instructional Leadership: A Developmental Approach, Boston, MA: Allyn and Bacon.

Gronn, P. (2000), Distributed Properties: A New Architecture for Leadership, Educational Management and Administration, Vol. 28, No.3.

Gurr, D. (2001), Directions in Educational Leadership, Hot Topics, No.5, ed. Peter White, www.qcel.edleaders.edu.au/pubs/52001.html.

Lambert, L., Walker, D., Zimmerman, D., Cooper, J., Lambert, M. and, Gardner, M., . (2002). The constructivist leaders (2nd ed.).New York: Teachers College Press.

Leithwood, K. and Jantzi, D. (2000), The Effects of Transformational Leadership on Organisational Conditions and Student Engagement with School, Journal of Educational Administration, 38.

Schlueter, K., and Walker, J. (2008).Selection of school leaders: A critical component for change. NASSP Bulletin, 92(1), 5-18. Sergiovanni, T. J. and Starratt, R. J. (1993). Supervision: A redefinition. New York: McGraw Hill, Inc.

Silns, H. and Mulford, B. (2002), Leadership and School Results, Second International Handbook of 4Educational Leadership and Administration (in press).

Spillane, J., Halverson, R. and Diamond, J. (2001) Towards a Theory of Leadership Practice: A Distributed Perspective, North western University, Institute for Policy Research Working Article.

Whitaker, K. (2002). Principal role changes and influence on principal recruitment and selection: An international perspective. Journal of Educational Administration, 41(1), 37-54. 
